\title{
The Betterment Levy and Time Parameter in the Light of Existing Legislation
}

\section{The Origins of the Problem}

Construction of technical infrastructure, to which necessarily should be included water supply or sewerage network, charges in accordance with the provisions of the Law on Real Estate, the property owner or the perpetual user, who does not have the obligation to pay annual fees or have payed any charges for the whole perpetual time of use. The necessary condition is that the construction of a technical device was carried out with the participation of the Treasury, local government units, and funds from the budget of the European Union or other foreign sources not reimbursable. The above financial burden does not apply to property held in the zoning plan for agricultural or forestry objectives. In the absence of a local plan, as agricultural or forestry estate considered are properties shown in the cadastre as farmland or forest land, as well as wooded and bushy and included in the estate mining land, wasteland and roads, if it has not been established for them, zoning and land development [7].

The increase of the market value of the property, occurring as a result of the construction of technical infrastructure, is associated with the obligation to make a betterment levy to the commune. These fees may be established within three years after the creation of conditions for connecting the property to the device. The commune may proceed to charge fees if, on the day of creation of conditions for connecting the property to the network a resolution of the commune council to establish the percentage rate of the fee was in force. The betterment levy amount is not more than $50 \%$ of the increase in the value of property due to the construction of the device. In the situation when the owner or perpetual user expenditures have been incurred for the construction of the device, such expense reduces the amount payable in respect of the calculated fee $[1,7,9]$.

* University of Agriculture in Krakow, Faculty of Environmental Engineering and Land Surveying, Department of Land Surveying, Krakow, Poland 
As stated in the Law on Real Estate, determination of the amount of the fee is made after obtaining the opinion of property valuer. When carrying out the valuation of the property from the title, referred to in this publication, its value should be determined without regard to the components. Real estate subject to the payment may be in varying degrees distant from the technical infrastructure, which significantly affects the costs, which have to be incurred because of the real estate connection to the main network. Thus, the increase in the value of the property when connected to the network will be different for each land under a betterment levy. This is due to the valuation rules that impose on the property appraiser the duty taking into account in the elaborated appraisal report the estimated distance of the real estate from the network built and conditions of its connection [7].

Another rule, when determining the value of the property, is associated with the perpetual users and in accordance with Art. 144 Paragraph 2 of the Law on Real Estate, if they are obliged to pay a betterment levy then the value determined before and after the construction of technical infrastructure refers to the property as a matter of right of perpetual use. The last and most important principle having been reflected in amount of the fee relates to the level of prices. The value of the property, to accrue mentioned charges, is determined by condition of the property before the construction of the technical infrastructure and according to the condition of the property after the construction. While the the level of prices, for which the appraiser is required to estimate the value of the property, is related to the date of the decision to establish the present fee. It should be noted that the decision may be made within three years from the date of the existence of conditions for connecting the property to the technical device.

\section{The Rules of Formal Setting of Betterment Levy}

Determining the betterment levy is carried out on the basis of a procedure that is a typical administrative proceeding. In the course of its activities the general rules of proceedings of the kind should be applied, such as [1]:

- the rule of law,

- the principle of control and supervision of compliance with the law in the proceedings,

- the principle of objective truth,

- the principle of taking into account of the public interest and the legitimate interests of citizens,

- the principle of deepening public confidence in state bodies and the impact of state bodies on awareness and legal culture of citizens,

- the principle that authorities are required to provide factual and legal information,

- the principle of active participation of the parties in the proceedings,

- the principle of persuasion, 
- the principle of the speed of the proceeding,

- the principle of written form,

- the principle of two-instances,

- the principle of sustainability of final administrative decisions and right to complain against administrative decisions to the Administrative Court,

- the principle of free evaluation of evidence.

The administrative decision to establish the betterment levy issued by the head of the commune, the mayor or the president of a city is a decision of the first instance. According to the law the act becomes final decision at the time of delivery to the party. The owner or perpetual user has the right of appeal against the issued decision within 14 days from the date of delivery to the appropriate local government appeal college that its scope of action includes the given property. If the party is not satisfied with the next decision, the next step is to file a complaint against the decision of the appeal body to the regional administrative court within 30 days from the date of delivery. The last possible step is the cassation appeal to the Supreme Administrative Court on the judgment of the Regional Administrative Court $[1,8]$ according to law.

At this point, should be emphasized the regulation inadequate to the conditions of the real estate market in Poland, according to which the commune has the ability to charge betterment levy within 3 years since the creation of conditions for the implementation of the property connection to the network. In the course of further analysis the authors of this publication show the real impact of the time factor on the amount of these charges and propose significant changes in the adoption of a new way of charging betterment levy. The solution of the problem seems to be a change in the evaluation of the date of the price level at which the value should be estimated.

\section{Methodology and Research Area}

The studies performed relate to one of the communes near Krakow, attractive in terms of housing, where, since 2004, successfully was carried out the construction of the sewerage network. In 2003, the commune council adopted the resolution that the amount of the betterment levy will be equal $50 \%$ of the increase in the value of the property resulting from the investment.

In order to carry out the studies the transaction prices were collected for undeveloped land intended for the zoning plans for single-family housing. Nearly 2000 data were collected, for the period 2003-2013. These data were divided into individual years. The time factor was eliminated in given calendar year, bringing all transactions as of December of a given year.

For this purpose, a linear regression model was used based on the the average values and standard deviations, in marginal distributions, determined on the basis of the results of the sample and taking into account the correlation coefficient of $X$ with respect to variable $Y$ [2]. 
The correlation coefficient indicates the direction and strength of the relationship between the analyzed variables, which in this case enables determination whether a set of prices needs to be updated.

The strength of the correlation can be determined at three levels [2]:

1. weak correlation

2. average correlation

3. strong correlation

$$
\begin{aligned}
|r| & \leq 0.3, \\
0.3<|r| & \leq 0.8, \\
|r| & >0.8 .
\end{aligned}
$$

If the received value of the correlation coefficient corresponds to its size at the first level, then the prices can be considered as valid for the investigated time period.

Update of prices was carried out according to the following formulas [2]:

$$
\begin{gathered}
c_{i(t)}=c_{i}+B \cdot\left(t_{a}-t_{i}\right) \\
B=r \cdot \frac{\sigma(c)}{\sigma(t)}
\end{gathered}
$$

where:

$c_{i}$ - transaction price of the $i$-th property,

$B$ - regression coefficient,

$t_{a}$ - update date (expressed in months),

$t_{i}$ - the date of of the transaction (expressed in months),

After eliminating the time factor as a differentiating element of the transaction prices, the data set referred to, can be used for the valuation of the research object in the comparative approach $[5,6]$. Carrying out the valuation of the same plot of land according to the level of prices as of December of each calendar year will be the basis to verify the thesis that the betterment levy is strictly correlated with the date of calculation.

\section{Results}

The object of the research, subject to the valuation was an undeveloped parcel of land with an area of $1000 \mathrm{~m}^{2}$. The subject property was valued using average price adjustment. For this purpose, from the collected base 20 to 25 data were selected, for each year and for each valued condition of the property (the real property with access to sewage and the real property without access to the network). Selected data concerned only properties with characteristics similar to the property being valued. Valuation of the same property at the price level as of December of each calendar year gave the basis for calculating the amount of the fee in the investigated period. Partial and final results of the calculations leading to the determination of the fee value were collected in Table 1. 
Table 1. Changes in the market value and the amount of the betterment levy in the years 2003-2013

\begin{tabular}{|c|c|c|c|c|c|c|}
\hline Year & $\begin{array}{l}\text { The value in the } \\
\text { state before the } \\
\text { construction of } \\
\text { the network } \\
\text { [PLN] }\end{array}$ & $\begin{array}{l}\text { The value in the } \\
\text { state after the } \\
\text { construction } \\
\text { of the network } \\
\text { [PLN] }\end{array}$ & $\begin{array}{c}\text { The } \\
\text { betterment } \\
\text { levy } \\
\text { [PLN] }\end{array}$ & $\begin{array}{l}\text { The percentage } \\
\text { difference in } \\
\text { comparison to } \\
\text { the previous } \\
\text { year [\%] }\end{array}$ & $\begin{array}{c}\text { The } \\
\text { difference in } \\
\text { percentage } \\
\text { compared to } \\
\text { the } 2003[\%]\end{array}$ & $\begin{array}{l}\text { The amount } \\
\text { difference } \\
\text { compared to } \\
\text { the previous } \\
\text { year [PLN] }\end{array}$ \\
\hline 2003 & 39900 & 43400 & 1750 & - & - & - \\
\hline 2004 & 41200 & 44800 & 1800 & 3 & 3 & 50 \\
\hline 2005 & 51900 & 56400 & 2250 & 25 & 29 & 450 \\
\hline 2006 & 77400 & 84100 & 3350 & 49 & 91 & 1100 \\
\hline 2007 & 111900 & 121600 & 4850 & 45 & 177 & 1500 \\
\hline 2008 & 201500 & 219000 & 8750 & 80 & 400 & 3900 \\
\hline 2009 & 175500 & 190800 & 7650 & -13 & 337 & -1100 \\
\hline 2010 & 143500 & 155900 & 6200 & -19 & 254 & -1450 \\
\hline 2011 & 167100 & 181600 & 7250 & 17 & 314 & 1050 \\
\hline 2012 & 155500 & 168700 & 6600 & -9 & 277 & -650 \\
\hline 2013 & 138700 & 150700 & 6000 & -9 & 243 & -600 \\
\hline
\end{tabular}

The estimated market value according to the condition of the property before the construction of the network takes into account the lack of feasibility of the connection to the sewerage network. And the market value according to the condition after the construction of the network, refers to the situation when there is a possibility of the connection of the real estate to the sewage network. The measurement results of the test object in the first and second case, differ from each other, and this difference is not constant during the period (Fig. 1).

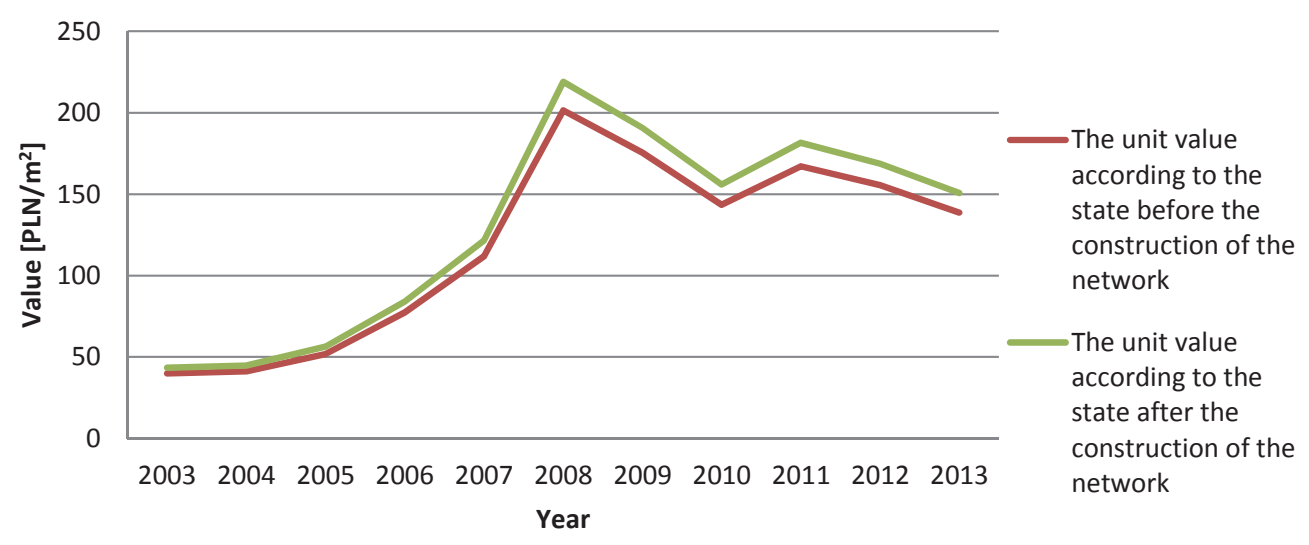

Fig. 1. Change in the estimated market value 


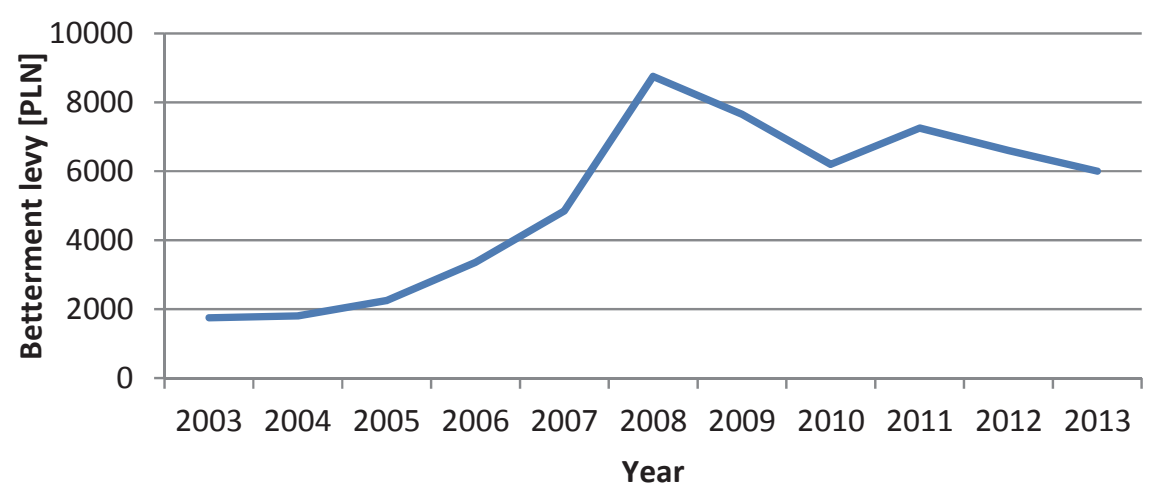

Fig. 2. The betterment levy in the analysed period

As can be seen in Figure 2 changes of the charge of betterment levy is a faithful reproduction of changes in the level of estimated market values. In 2003, the fee is 1.7 thousand PLN, then gradually grows as is an increase in market value. The highest value of the fee falls on the year 2008 and this is the amount of 8.7 thousand PLN, then from 2009, follows a correction as is adjusted the level of prices in the local market, which reflect the estimated market values.

\section{Summary and Conclusions}

Relying on statistical analysis of the method of determination of the betterment levy, resulting from the prices level at the date of calculation of the levy, significant differences in the amount of those charges in consecutive years can be observed. The research was conducted for over 11 years and did not show any three-year period in which the charges would be at the same level (Fig. 3). This is important from the point of view of the rights owned by the commune giving it the right to calculate charges for 3 years period from the arising of conditions for the connection of the property to the network. Correction of charges in one year is for the benefit of the community in another however for the benefit of the property owner (Fig. 3).

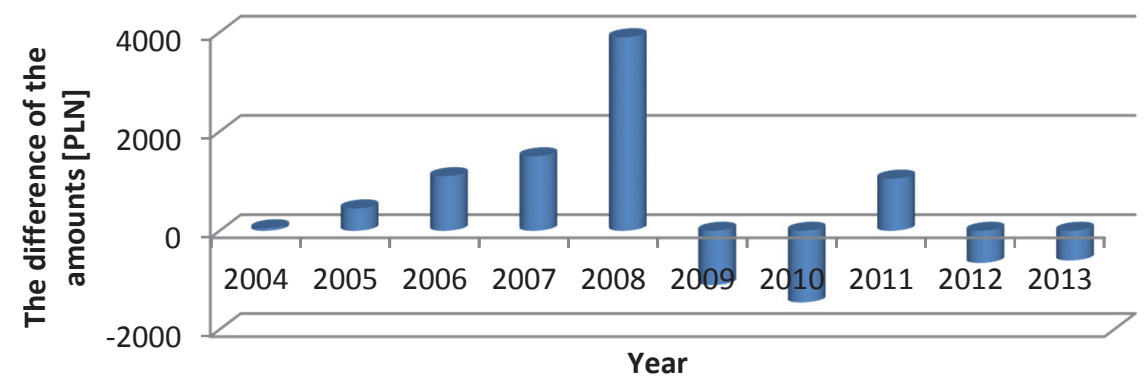

Fig. 3. The difference of the amounts of betterment levy compared to the previous year 
The study shows an unambiguous conclusion, that in the case of charging of betterment levy the date of the price level should be the same as the date of arising of the conditions of the use of the device, and not the date of the decision of the amount of the levy.

It seems that the specified new way of betterment levy charging, related to a change of the criterion for the adoption of the date of the price level, will cause such actual state, in which the amount of the fee will reflect a real increase in the value of real estate in connection with the construction of the device. In this situation, it will be free from the decisive factor which is the parameter of time.

The benefits of these changes may be considered for both the commune and the owner. Thanks to them, both the municipality and the owner will bear real consequences of the fee billing.

\section{References}

[1] Bogusławska-Klejment J., Cymerman R.: Opłaty adiacenckie w orzecznictwie i w praktyce. Wyd. Educaterra, Olsztyn 2010.

[2] Czaja J., Parzych P.: Szacowanie rynkowej wartości nieruchomości w aspekcie Międzynarodowych Standardów Wyceny. Wyd. AGH, Kraków 2007.

[3] Cymerman R., Bajerowski T., Kryszyk H.: Prognoza skutków finansowych uchwalenia miejscowego planu zagospodarowania przestrzennego. Wyd. Educaterra, Olsztyn 2006.

[4] Cymerman R., Hejbudzki M., Gwiaździńska-Goraj M., Konieczny D., Kotlewski L., Kurowska K., Kryczyk H., Morze A., Podciborski T., Rząsa K., Schiling P., Zawadzka J.: Planowanie przestrzenne dla rzeczoznawców majatkowych, zarzadców oraz pośredników w obrocie nieruchomościami. Wyd. Educaterra, Olsztyn 2006.

[5] Powszechne Krajowe Zasady Wyceny. Polska Federacja Stowarzyszeń Rzeczoznawców Majątkowych, Warszawa 2008.

[6] Prystupa M.: Wycena nieruchomości przy zastosowaniu podejścia porównawczego: omówienie standardu wraz z przykładami zadań. Wyd. 2. Polska Federacja Stowarzyszeń Rzeczoznawców Majątkowych, Warszawa 2003.

[7] Rozporzadzenie Rady Ministrów z dnia 21 września 2004 r. w sprawie wyceny nieruchomości i sporzadzania operatu szacunkowego. Dz.U. 2004 nr 207 poz. 2109 as amended.

[8] Szachułowicz J.: Gospodarka nieruchomościami. Wyd. Prawnicze PWN, Warszawa 2001.

[9] Ustawa z dnia 21 sierpnia 1997 r. o gospodarce nieruchomościami. Dz.U. 2014 poz. 518 as amended.

[10] Ustawa z dnia 27 marca 2003 r. o planowaniu i zagospodarowaniu przestrzennym. Dz.U. nr 80 poz. 717 as amended. 